\title{
Trade Interests in Foreign Policy of the Global South*
}

\author{
Zdzisław W. Puślecki \\ Adam Mickiewicz University, Poznań, Poland
}

\begin{abstract}
In this research work, the author focuses on the analysis of the trade interests in foreign policy of the Global South. What indicates the importance and innovativeness of the research is the presentation of the new models of the foreign trade policy and trade interests of Global South. First of all, it must underline that in the new theoretical terms in the demand for trade policy very important is factor specificity. The low specificity of factors means that factor returns are equalized throughout a region's economy. Moreover, some factors are stuck in their present uses; therefore, factor returns are not equalized throughout a region's economy, but are industry specific. The main objective of the research task is to give a comprehensive analysis of the models of foreign trade policy, trade interests indicated by export orientation and import sensitivity, protectionistic pressures in different political system and different types of authoritarian regimes of Global South, the level of protectionistic pressures, the rise of qualitatively new politics in North-South relations like bilateral tendencies. It should be stressed that free trade in itself is not responsible for economic growth, but more significant are the determining macroeconomic stability and increasing investment of Global South.
\end{abstract}

Keywords: trade policy, public choice, liberalism, protectionism, authoritarian regimes

\section{Introduction}

Due to technical progress and the growth of economic ties between particular countries, participants in the world economy, the benefits resulted from liberalized international trade and from the freedom of movement of foreign direct investments become bigger not only for the industrialized countries but also for the so-called "emerging markets", that is to say, the countries find themselves on the stage of the accelerated development. It must be emphasized that there is the need for new approaches to trade cooperation in light of the forces that are currently re-shaping international business. It suggests that the multilateral trading system will need to adjust to developments in trade and in the trading environment. The key of trade developments within the broader socio-economic context is especially the rise of global supply chains, the general shift of trade power away from the West towards Asia.

In the process of the development global economy, apart from the phenomenon of growing interaction between various countries and business which participate in the international economy, in the course of increasing competition in the area of new markets and of capital investments, the control measures in international trade can be observed. They are the subject of multilateral negotiations concerning the foreign trade liberalization issues, negotiations conducted on the World Trade Organization (WTO).

\footnotetext{
* Paper prepared in the framework of the Grant OPUS, Narodowe Centrum Nauki -NCN (National Centre of Science-NCS), Nr UMO - 2013/11/B/HS5/03572.

Zdzisław W. Puślecki, Full Professor, Faculty of Political Science and Journalism, Department of International Economy, Adam Mickiewicz University.
} 


\section{Research and Methodology}

Realistic point was important trends in the global trade regime during the world economic crisis. The protectionistic pressures revenues played very important role in this time of the economic development. The main aim of the article is the indication of trade interests in the political economy. The main objective of the research task is to present the political economy models of foreign trade policy, trade interests indicated by export orientation and import sensitivity, protectionistic pressures in different political system and different types of authoritarian regimes.

The analyzed problems were solved with the use of both quantitative and qualitative research methods. The main research method applied in this economic analysis, was a method of scientific study used for splitting the whole (of individual items, their sets, phenomena) by means of logical abstraction. It also used the analogy (comparative) method, which consists in finding similarities and differences between the items under study, the documentation method and statistical methods. It applied the descriptive method, as well as methods of descriptive statistics and forecasting. Additionally, it used the methods of deductive and inductive forecasting.

\section{Discussion}

\section{The Models of Foreign Trade Policy}

Traditionally, political economy models of trade policy have tended to focus on the demand for protection, with factor endowments driving political reactions to exposure to international trade. Such model simply assumed that adversely affected economic agents would organize to seek protection, which would be afforded to them by their elected representatives in the political system. The supply side for trade policy was either ignored or underspecified in most model (Thies \& Porche, 2007).

In the foreign trade policy theory interesting are the reviews of Alt et al. (1996) and Nelson (1988) about the demand for trade policy in terms of the theoretical importance of factor specificity. Factor specificity refers to the ease with which factors (land, labor, and capital) can move from one sector to another in an economy. The two dominant approaches to explaining the demand side of trade policy used radically different assumptions about the specificity of factors. The Heckscher-Ohlin model, used by Rogowski (1989) in his seminal contribution "Commers and Coalitions", assumes very low-factor specificity. The low specificity of factors means that factor returns are equalized throughout a region's economy. Producers should export goods that intensively use their abundant factors and import goods that intensively use their scarce factors, with the result that owners of abundant factors will favor free trade and owners of scarce factors will favor protectionism. Trade policy coalitions will therefore be organized along factor or class lines. On the other hand, the Ricardo-Viner assumes that some factors are stuck in their present uses; therefore, factor returns are not equalized throughout a region's economy, but are industry specific. Trade policy coalitions should form along the lines of exporting versus import-competing industries.

Neither of these models explains how preferences over trade policies are actually translated into political action (Alt et al., 1996). In a discussion of the endogenous tariff literature, Nelson (1988) noted that the mobility costs of the specific-factors model may be a result of productivity differentials, labor union activity, or individual preferences for membership in a given geographic area, industry, or firm (i.e., some form of solidarity). In all of these cases, one can derive a link to preferences for tariff policy, "but without additional information on why the specific-factor model is chosen, it does not tell us much about political organization". 
Alt et al. (1996) suggested that one can begin to understand this process by assuming that rational individuals make cost/benefit calculations. The Heckscher-Ohlin and Ricardo-Viner models tell us the benefits that individuals hope to receive, but the costs of collective action also intervene as they organize to archive those benefits in the political system. Olson (1985) argued that small groups with specialized interests are easier to organize and more effective in securing economic rents than large groups with diffuse interests. Small groups are better able to control free riders than large groups, and groups with specific or homogenous interests can more easily coordinate and target their activities than groups with diffuse or heterogenous interests. This approach is thought to explain the success of agricultural producer groups in developed countries in organizing for protection as well as the inability of agricultural producer group to organize in developing countries (Anderson, 1995; Coleman, 1998; Olson, 1985; Olson, 1986; Sheingate, 2001).

However, Nelson (1988) pointed out that we should not assume that organized interests will be equally responsive to all issues. Institutionalized interaction among actors may help to explain systematic patterns of action, especially as institutions created for specific historical purposes may outlive those purposes. Alt et al. (1996) suggested that if a particular group has paid the fixed costs of establishing collective action and developed well-worn channels of access to public officials, it may defend its trade policy preferences even when the stakes are low because the marginal costs of action are low. It may be the case that "a much more affected but inchoate group does nothing because the start-up costs of organization are too daunting". Past strength of an organization should therefore be an important intervening variable predicting group action on trade policy. Further, as Nelson (1988) argued, once these institutions exist, supply-side interventions may also affect their usefulness as some are deemed legitimate or illegitimate aggregators of interest. Thus, we must examine the way in which economic institutions and political institutions interact. Most economic models simply assume that a model of the economy is a model of the demand side for trade policy, but Nelson (1988) suggested that we must elaborate the mechanisms by which demand is articulated to the suppliers of trade policy (p. 810). For a good overview of this argument, especially as it pertains to agriculture (Thies \& Porche, 2007).

If the political systems rewards small sectoral groups, then individuals will not pay the costs of organizing large inter-sectoral coalitions. If the political system rewards large mass movements (i.e., majoritarianism), then individuals will have to pay the costs of organizing large inter-sectoral coalitions in order to archive any benefits. Collective action costs and political institutions are interactive with factor specificity. They suggest that Rogowski's (1989) Heckscher-Ohlin framework requires low factor specificity, low collective action costs, and domestic political institutions that favor mass movements. The Ricardo-Viner framework used by the endogenous tariff literature requires that factors are specific, collection action costs are high, and institutions are less majoritarian, with changes in any of these three variables also affecting the type of coalitions that form.

In the state as a rational dictator model, the state may be seen as either pursuing "good government" goals along a social welfare function or intervening in the economy for their own self interested model of the state views politicians as offering preferential trade policy to economic actors in exchange for political support (Magee, Brock, \& Young, 1989; Grossman \& Helpman, 1984). On the other hand, pluralist theory typically view the state as a neutral aggregator of demands from groups in society. The supply of trade policy is then determined by the balance of power on any given issue. The supply side of trade policy is relatively undeveloped theoretically, and yet a crucial part of the equation. A variety of different characteristics of the political system are posited to affect the supply of trade protectionism, such as politicians incentives to cultivate 
personal votes, the size of electoral districts, party fragmentation, federalism, presidential versus parliamentary systems, and so on (Nielson, 2003; Rodrik, 1995; Rogowski, 1987a; Rogowski, 1987b).

On a theoretical level, understanding the choice of trade policies in countries is very important. A survey of economists in 1984 suggested that one of the few things they agreed on was that, under most conditions, tariffs, and quotas reduce the general welfare (Frey, 1984). The stubbornness of protectionism in the face of international and academic pressure against it has led economists to seek explanations. These explanations range from the simple ignorance of politicians to arguments about the rationality of protection for "infant industries" and "optimal tariff levels" in developing states. Faced with this frustrating question, scholars have increasingly turned to political answers in order to explain the choice of what would seem to be an "irrational" policy (Frey, 1984; Nau, 1989; Nelson, 1988).

\section{Trade Interests Indicated by Export Orientation and Import Sensitivity}

The evidence considered provides substantial support for the argument that the trade interests of their constituents, as indicated by export orientation and import sensitivity of their district, influence policymakers' behavior on political and security issues. These effects are mediated by party and the heterogeneity of constituency and are consistent in both roll-call voting and sponsorship activity (Kleinberg \& Fordham, 2013). Export orientation appears to be somewhat more important than import sensitivity. Both have substantively meaningful effects on sponsorships, but only export orientation is a statistically significant predictor of roll-call voting (Kleinberg \& Fordham, 2013).

About the liberal argument it is important to underline that trade reduces international conflict and promotes cooperative foreign policies. The first is that the benefits of international trade indeed appear to influence policymakers' attitudes toward trading partners as the liberal argument suggests (Kleinberg \& Fordham, 2013). These results complement similar effects it can found in surveys of mass public (Fordham \& Kleinberg, 2010).

The second conclusion is an important qualification to the liberal argument, though not one that is at odds with its underlying logic. Because the aggregate benefits of international trade are not shared equally within the trading states, trade's political effects do not apply to everyone. The fact that some people can expect their income to decline as a result of international trade is critically important for whether is actually reduces conflict between trading partners. These people could contribute to demands for a less-cooperative foreign policy as well as for trade protection. In principle, the winners in the trading relationship should be able to remove this motive by compensating the losers out of the aggregate benefits of trade. In practice, such compensation is not always offered (Kleinberg \& Fordham, 2013).

It is important to underline that legislative measures do not always have immediate effect on national policy (Kleinberg \& Fordham, 2013). For example the East Asia Security Act did not became law, though it had substantial support. Many of the other measures have a large number of cosponsors. The executive branch can and does block so many measures that would harm for example US relations with China. These legislative measures are still consequential. The cost of blocking them rises with the number of members who support them. Facing an unfavorable domestic political environment, the executive might set aside cooperative measures that it would otherwise have proposed. Moreover, for example the Chinese government takes not of hostile proposals in Congress, so they may affect political relations even if they not become national policy (Kleinberg \& Fordham, 2013). 
A bilateral relationship, are also very important. This relationship is clearly unusual in some key respects. Relations USA with China are far more uncertain than relations with other major American trading partners, many of whom are longstanding democratic allies. Those harmed by trade with this other states would have difficulty convincing other Americans to view them as potential enemies. However, it does not follow that trade can have no effect on these relationships. That are points of tension and disagreement even among the closest of allies. Those who lose from trade might support less cooperative positions on these differences, perhaps using them as the basis for limiting the trading relationship. The 1996 Helms-Burton Act's effort to force European firms to adhere to American sanctions against Cuba is on possible example of such a measure (Kleinberg \& Fordham, 2013). Special research would be necessary to test the domestic political effects on trade in the context of friendlier international relationships, but there is no reason to expect these effects to be confined to the relations between the United States and China (Kleinberg \& Fordham, 2013).

\section{Protectionistic Pressures in Different Political System}

It is important to indicate, that the role of trade unions in different political systems may be, to a high degree, different. In authoritarian systems it is, as a rule, smaller than in democratic systems. It would seem that if protectionistic pressure on the part of trade unions is weaker, the situation for economic growth is much better. Following that line of reasoning we could come to conclusion that the authoritarian system is better for the effectiveness of the labor market. The examples of Chile, South Korea, Singapore and Turkey from the seventies and early 1980s could confirm that point of view. In many cases during those two decades the authoritarian regimes persecuted trade unions and put restrictions on basic labor rights. During that period of oppression, South Korea, Singapore and Turkey experienced a spectacular growth in the sector of processing industry and in the growth of demand for labor. Growing profits and the demand for labor in a processing industry, caused a general growth of prosperity of the employed. Although similar results were not noted immediately during the authoritarian phase of development in Chile, a number of observers express the opinion that the reforms introduced at that time helped to reorganize Chilean economy in the nineties. The application of democratic rules, on the other hand, may lead to lower productivity of labor force. In a number of years different democracies had to use significant financial resources for the employment of those who belonged to trade unions like for example in the European Union.

A different point of view says that government legislation concerning the labor market may be applied more effectively in an authoritarian system than in a democratic one. The authoritarian regimes often make use of individual interests of given circles. In most democratic countries there is no broad enough basis that would allow to use labor market policy for gaining the support from pressure groups, the urbanized labor marked elite included. The major difference between authoritarian and democratic regimes lies in the level of the outside influence. In a well functioning democracy, the outside opinions are also taken into account and there occur some limitations which come from the outside, which restricts the achievements of given groups of interest. In a dictatorship, a government cares only that those groups are not too strong.

There is, however, a number of democracies among the industrialized countries where an effective labor market exists. There is also a number of democracies with effective labor market policy among the developing countries. Similarly, in the countries in which the transformation from the authoritarian regime towards a democracy is taking place, avoiding unfavorable phenomena on a labor market is often a priority. For example, the Chilean government moved towards democracy and to free trade unions without home income growth. The 
end of oppression in South Korea, in 1987, started the partnership relations in full of conflicts industry (Banerji \& Ghanem, 1997).

It is worth considering which of the two points of view presented above should be given support, that is, which of them is the proper one. The analysis of that problem may be based on the Grossman and Helpman (1994) model. This model describes economic development on the basis of two sectors-urbanized, regulated processing sector, and rural, unregulated agricultural sector. The protection of the labor market, especially of minimum wages, is usually applied in order to bring the benefits for the employees of the regulated sector, since the sector of unregulated employees does not come under the legislation concerning the labor market.

The sector of regulated employees, and also the owners, demand from the government that it leads an economic policy that is favorable to them. The employed demand high minimum wages, while capitalists demand high profits. Both groups demand the restrictions on the degree of economy openness. In a closed economy, higher market minimum wages and higher profits are usually connected with higher prices for home consumers, and this is not easy when those consumers are free to buy the substitutes in form of imported goods. Thus, incomes in an economy may be created by protection and later divided among the employees of the regulated sector and the capitalists, although sometimes the government itself takes a part of those incomes (Banerji \& Ghanem, 1997).

A government conducting an economic policy takes into account a number of factors. Firstly, it has to decide the degree of obtaining the resources, that is to say, how much from those resources it wants to obtain. Hence the importance of investments of future economic growth, and also of defining the possibilities for keeping the power it is currently holding. Secondly, the government should define the scale of support from each of the pressure groups that can influence the situation. The position and importance of each group for the development of political processes should be considered. For example, in the country where the regulated labor market is divided, and politically weak, only the capitalists may have a deciding voice in political processes. And the contrary also happens - in the societies where the labor market is organized, it may play the important role in mobilizing voters.

\section{Different Types of Authoritarian Regimes}

Interesting question is, which authoritarian regimes are most politically liberal? Among the authoritarian regime types often identified in the literature, multiparty, and to a lesser extent single-party, regimes will tend to have the largest selectorates. Therefore it argue that multiparty and single-party authoritarian regimes will have more open trade policies than other authoritarian regime types. More specifically in the Wright data (Wright, 2008a; 2008b;), the coding is divided into four categories: single-party, military, monarchist, and personal regimes. In the case using these data, it can expect that single party regimes will tend to have more liberal trade policies than other authoritarian regime types. For the test using the Hadenius and Teorell (2007) data, it can expect that multiparty regimes will tend to have more liberal trade policies in comparison with any of the other four regime types (single-party, military, monarchy, and personal regimes) (Hankla \& Kuthy, 2013).

The second component institutionalization argument is that regime stability encourages free trade policies in authoritarian systems. More institutionalized autocratic regimes are better able to co-opt dissent and should therefore tend to enjoy longer and more stable tenures. As a regime's stability increases, the time horizons, in turn produce powerful incentives to enact policies that will benefit the country's economy in the long run rather 
than just shore up support for the leadership in the immediate future. It is important to underline that, even kleptocratic dictators have good reason to maintain the health of their national economies, if only to provide sources of future loot. By contrast, authoritarian leaders sitting atop unstable regimes and fearing removal will not be thinking about the long-term future. Instead their focus will be providing immediate benefits to their supporters in order to remain in power. As a consequence, the leaders of more stable autocratic regimes will be more likely to provide the public good of free trade, while those whose hold on power is precarious will tend to rely on particularistic goods such as protectionism to keep their winning coalition intact (Hankla \& Kuthy, 2013).

This argument follows the logic presented by Hankla (2006) on time horizons and trade policy decisions in democracies, expect that it concerned here with authoritarian stability rather than electoral volatility. It is also similar to the argument developed by Wright (2008b) linking long time horizons in authoritarian regimes to the effectiveness of foreign aid (a rare piece of research exploring the policy implications of regime stability under dictatorship). Indeed, the prospects for stability to matter perhaps are greater in authoritarian regimes than in democracies, because for ruling groups in the regimes, losing power often results in death or imprisonment. Therefore, the pressure for protectionism in an attempt to gain short-term support in new unstable regimes is likely to be even greater for authoritarian governments than for those in a democracy. Additionally, truly stable authoritarian regimes tend to have individual leaders with very long time horizons (far beyond those of stable democratic leaders), providing them with stronger incentives to choose policies, like free trade, that may contribute to long-run economic growth (Hankla \& Kuthy, 2013).

Seeking to understand trade policymaking in authoritarian regimes is all the more pressing because so few others have spent time on the issue. It is worth taking a moment, however, to consider two rare articles that touch on trade policymaking under autocracy. It must be emphasized that regime type is not as important as an indicator of trade openness as the number of veto players with influence over policy change. They find that in post-communist East-Central Europe, both democracies and autocracies with more veto players also enjoyed freer trade. This link, they believe, is a product of incorporated a wider variety of voices into policymaking, thereby reducing the ability of governments to depend on patronage to stay in power (Hankla \& Kuthy, 2013).

It is important underline that authoritarian regimes do not behave similarly to one another with regard to their trade policies and it is a mistake to consider such regimes as identical (Hankla \& Kuthy, 2013). Hadenius and Teorell (2007) found that multiparty regimes have significantly lower levels of trade protectionism than single-party autocracies, monarchies, non party regimes, and military juntas. As a robustness check, it also find significant support for Wright data (Wright, 2008a; 2008b). In addition it finds evidence using both the Hadenius and Teorell and Wright for conclusion that more stable regimes will, on average, have more liberal trade policies. The effect of individual leader duration appears weaker, but there is some limited evidence of its importance.

Scholary understanding of the behavior of authoritarian regimes will need to be tied closely to an examination of their institution and institutionalization. Perhaps the most fruitful arena for future research will be to focus on the specific preferences of selectorates composition and policy outcome (Pepinsky, 2008). Such research could answer the question of how different formal institutions in autocratic system mediate these preferences in the formation of policy. It could also shed light on the types of selectorates likely to exist in different types of authoritarian regimes. A deeper examination of these questions can extend the knowledge of how autocratic institutions mediate social and elite preferences in the development of policy in a wide variety 
areas (Hankla \& Kuthy, 2013).

\section{The Level of Protectionistic Pressures}

The above arguments show that the policy is defined by political factors (including the type of the government and the burdens resulting from obligations towards employees and capitalists), and by economical factors (wages, prices, the structure of production and consumption). On the basis of the present discussion, we can present two equations, one pertaining to the level of protection, and the second pertaining to the national economy and deformation of wages.

(1) $\pi=\mathrm{f}(\mathrm{e}, \mathrm{l}, \mathrm{k}, \mathrm{R})$

(2) $\varphi=f_{1}(\pi, e, l, k, R)$.

The level of protection $(\pi)$ depends on the economic parameters (e), a relative political importance of urbanized employees and capitalists ( 1 and $\mathrm{k}$, respectively), and on the type of the government $(\mathrm{R})$. Deformation of wages is, moreover, the function of $\pi$ and of $\mathrm{e}, 1, \mathrm{k}$ and $\mathrm{R}$. In case of a small economy, economic parameters that can influence $\pi$ and $\varphi$ include flexible consumer and producer prices, demand flexibility, wages and the demand for labor force, and also the price of goods on an international market.

One can expect, a priori, that the growth of $\pi$ is dependant on 1 and $\mathrm{k}$. If interest groups become stronger, the pressure to form incomes based on protectionism may become stronger. The influence of $\mathrm{R}$, that is to say, the influence of a political authoritarianism on the level of protectionism, that is to say, $\pi$, depends on the fact whether the opinion, that the level of protectionism depends on the effects of democratization, is correct. It is also thought that the increase of the deformation of wages depends on $\pi$ and 1 , while its decrease depends on $\mathrm{k}$. As long as the incomes are obtained from trade protections, those incomes can be handed over to urbanized employees. An important problem in case of urbanized labor force as an interest group with growing strength is the fact that urbanized employees may gain a big share in the division of incomes but the growth of political importance of the capitalists may cause that the shared incomes, handed over to the labor force in regulated sectors of economy will become smaller (Banerji \& Ghanem, 1997).

There is no doubt that it is easier for wealthy rather than poor societies to choose democracy. Since those wealthier societies at the same time have a tendency to a bigger openness, the direction of cause-result events may run from the openness of society to the political system, and not, as was suggested earlier, in the opposite direction. The research showed also that the level of education plays an important role in this respect. The countries with a higher level of education of labor force are more open.

On the basis of the earlier considerations, one can come to the conclusion that authoritarian systems have a tendency towards a broader application of protectionism than democratic systems, and that, in turn, the trade restrictions accompany significant deformations of wages on the labor market. This opinion may be justified on the basis of the observations of the situation in a number of countries.

Freedom of association is one of the elements of good management and the necessary condition for development. The authoritarian governments do not respect, however, the freedom of association, which is connected with the policy of trade restrictions and with the deformations on the labor markets. One cannot state, however, that improper or ineffective policy on the labor market belonged exclusively to authoritarian regimes or that authoritarianism automatically generates this kind of policy. There is a number of examples of authoritarian countries which do not conduct policies of that kind. The works of such authors as Fields or Freeman show that the repressions against the labor force are not necessary, if one wants to achieve a required 
economic growth.

Finally, it should be pointed out that there exists a close relation between democracy and an economic growth. There are well known examples of open societies that stimulate the economic growth. This is true mainly in case of highly developed and strongly urbanized countries. In the countries with a developed democracy, the pressure groups have a bigger opportunity for acting. The research shows that the presence of trade unions helps to accelerate the economic reforms. The benefits resulting from liberalization of the international trade are bigger when the trade unions exist in the sector of the economy under protection. The growth of import abilities leads to the decrease of wage pressures, and when the trade unions agree to that, such a situation allows for a better allocation of labor force in the economy. This is true both in the case of active and passive trade unions, although the effects are better in case of active trade unions.

The trade unions active on an urbanized labor market had a significant influence on the decisions of governments, in the course of multilateral trade negotiations within WTO. It was especially evident in the negotiations on lowering customs duties and non-tariff measures in steel, shipbuilding, textile and clothing industries, and in coal mining. In the so-called "sensitive" industries, which, for example, in the European Union were under special trade protection, the position of trade unions was very strong.

\section{The Bilateral Tendencies in Foreign Trade Policy}

The tendencies in international trade development can create changes in domestic markets, placing pressure on political actors to obtain aid from the government of Global South countries. There are also the groups which want to coordinate activities and change foreign trade policy. Global South countries provide the justification for protection of the internal single market to response to global competition. It is important underline that essentially, the government appears to supply protection for affected parties; yet, the overall impact on consumers, producers, and foreign competition is negligible (Thies \& Porche, 2007). Significant government ownership of the productive resources of a country has a negative effect on trade liberalization, while fragmentation of decision-making authority, expressed as fragmentation within the government and pluralism in society, has a positive impact on the liberalization of trade policy.

In the area of foreign-policy analysis has focused on "three i's": interest groups, international structure, and ideas. In the interests groups literature, government policy is viewed as the outcome of competition between groups for trade policies that benefit their industry (Nau, 1989; Milner, 1995; Milner \& Yoffie, 1989). International structure suggests that freer trade was a reflection on US interests and its hegemonic status after World War II, while a decline in free trade is a reflection of the US's hegemonic decline. The literature on ideas suggests that policy beliefs are reflected in laws and institutions. These laws and institutions, in turn, carry a type of inertia that continues to influence policy outcomes long after changes in international and internal structure would predict policy change. In contrast to these explanations government interests in the economy and in maintaining stability also play a large role in trade policy.

At one end, a multilateral forum like World Trade Organization (WTO) with near universal membership offers maximization of gains from trade and reduced transaction costs. However, a single state of Global South cannot expect to have much control over trade partners or liberalization agendas at the multilateral level. At the other end, a bilateral FTA often yields very small gains from trade and usually increases transaction costs by producing idiosyncratic sets of rules. But at the same time, a large state of Global South, can acquire a high level of control in terms of partners, issues and agenda selection, and sectoral exclusions or inclusions based on 
domestic political needs (Pekkanen, Solis, \& Katada, 2007). One can contend that industrialized of aggregate economic gains in the interest of national welfare (largest in multilateral forums) or seeking control over rules in line with political interests (greatest in bilateral forums).

It is important to underline that the liberalizing rules on agriculture, and other less competitive sectors, are no longer an acceptable political price for the economic gains bundled across sectors. Yet, this sort of vague statement fosters uncertainty for domestic actors at home in uncompetitive sectors like agriculture and in several cases, for example in European Union and Japan trade officials need to show that they have more concrete control for political reasons - an element more credible in a bilateral setting than a multilateral one (Pekkanen, Solis, \& Katada, 2007). Leading investor states negotiated also a web of bilateral investment treaties (BITs) (Radice, 2015). This situation may also indicate the back from globalisation to the mercantilist tendencies in the foreign trade policy.

As economic growth resumed in 2009, it was the so called emerging economies that recovered far more quickly, and it has become a cliche that the BRIC economies (Brazil, Russia, India and China), and China in particular, were driving a recovery that, at the level of aggregate global production and trade, was remarkably robust. Even if some of the bubble markets around the world remained deflated (US and most European housing most notably), once short-term speculative forces are taken into account the rising prices of food and industrial commodities reflected that recovery (Radice, 2015). This was a resumption of a decade-long growth trend in Africa as well as Asia and Latin America. The apparent return to slower global growth and renewed financial uncertainties in 2011 has not reversed the shift in the relative dynamism of North and South (Radice, 2015).

\section{Results}

The trade liberalization has a special positive significance in the global context. However the international trade policy is strongly affect by the force and trends of the world economy development. The changes are evident in the growing importance of international trade to national economies and to domestic groups within those economies, in the closer linkages between trade and other international issues. In this context it must be emphasis that on a theoretical level, understanding the choice of trade policies between liberalism and protectionism in countries is very important.

Question is how can we recognize the type of power, the type of rule? First of all, we should investigate what level of resources that a given government is going to achieve. If an authoritarian government is more or less corrupted than a democratic one, it will be creating the income, to a bigger or lesser degree, through protectionism. It will also appropriate some part of that income. Secondly, a given type of government may remain under the influence of different pressure groups. If an authoritarian government is trying, to some extent, to subordinate special pressure groups including the regulated labor sector, it will be, to some extent, generating incomes through protection and it will be turning over some part of them to those special pressure groups.

It should be pointed out that there exists a close relation between democracy and an economic growth. There are well known examples of open societies that stimulate the economic growth. In the countries with a developed democracy, the pressure groups have a bigger opportunity for acting. The research shows that the presence of trade unions helps to accelerate the economic reforms. The benefits resulting from liberalization of the international trade are bigger when the trade unions exist in the sector of the economy under protection. The growth of import abilities leads to the decrease of wage pressures, and when the trade unions agree to that, such 
a situation allows for a better allocation of labor force in the economy. This is true both in the case of active and passive trade unions, although the effects are better in case of active trade unions.

Trade policy takes on additional importance in economic battle of the valiant liberal reformers, fighting against self-dealing rent seekers profiting from inconsistencies of the transition economy. Many of the clientless policies that shelter rent seekers are impossible to maintain in the face of competition in the international economy. On the other hand, high tariff walls, export licensing, and artificial exchange rates provide numerous sources of rents for business people who are trying to promote their own loyalties. The reduction or the elimination of trade restrictions stimulates significantly the growth of the world trade exchange, while the foreign trade, in turn, is an important factor of the economic growth of individual countries.

Scholarly understanding of the behavior of authoritarian regimes will need to be tied closely to an examination or their institution and institutionalization. Perhaps the most fruitful arena for future research will be to focus on the specific preferences of selectorates composition and policy outcome. Such research could answer the question of how different formal institutions in autocratic system mediate these preferences in the formation of policy. It could also shed light on the types of selectorates likely to exist in different types of authoritarian regimes. A deeper examination of these questions can extend the knowledge of how autocratic institutions mediate social and elite preferences in the development of policy in a wide variety areas.

Further trade liberalization and improved framework policies would increase trade and promote growth. It must be emphasized that openness to trade is associated with higher incomes and growth and there are the need for new approaches to trade cooperation in light of the forces that are currently re-shaping international business. The key of trade developments within the broader socio-economic context is especially the rise of global supply chains, the general shift of trade power away from the West towards Asia. A major factor, was the even more remarkable transformation of China, as market reforms opened up its economy to foreign trade and investment, and unleashed an unprecedented growth dynamic that has continued, with only minor slowdowns. In the new circumstances for the development of the global economy and the global trade, People Republic of China seems to be a production superpower, able to change the world trade. In many areas it possesses comparative advantages. China may continue their development to specialize in electronics and increasingly in services. With or without further trade agreements, services will be more traded and trade policies will have to adjust to changes in the organization of global value change. The question raised is whether the West will see China's rise as an opportunity for cooperation or for conflict. Economic growth is generally more preferable in China to military and extensive expansion. With new investments, a country can transform its position through industrial expansion at home and sustain it through international trade. China is especially sensitive to the advantages of intensive growth and will not wish to disrupt essential economic arrangements that have been crucial to her success.

The integration of China and India into the world trade system may have increase aggregate welfare in the rest of the world by $0.4 \%$ but factor incomes in individual sectors may fall or rise by more than five per cent. Dealing with relative wage pressures and needs for structural adjustment due to rising trade integration will thus be important. The benefits from trade liberalization are transmitted through several channels like shifting production from low to high locations, relocation of factors of production towards sectors and firms with high productivity and rising incomes due to an increase in market size that supports more specialization, faster technology diffusion and stronger incentives to invest in "non-rival" assets. The former two effects include mostly static from international trade in goods, services and factors of production, while the latter entails 
dynamic growth effects. Significant static and dynamic efficiency gains - especially for South countries - could be reaped through further multilateral trade liberalization while global welfare gains from regional agreements are much more limited due to trade diversion. While fostering multilateral trade liberalization has proved difficult in the recent past and regional arrangements have been frequent, the former should remain priority due these larger benefits and despite the practical challenges of seeing through such reforms in a multi-polar world. This results are based on the "Partial multilateral" trade liberalization scenario based on multilateral cuts in tariffs $(50 \%)$ and transaction cost $(25 \%)$ relative to baseline.

It is important to underline that also fiscal consolidation will require major efforts in several countries. Fiscal pressures will build up in reverse areas over coming decades unless extensive fiscal reforms are pursued. Asia growth could be curbed further by damages from environmental degradation due inter alia to climate change, which are likely to affect these countries earlier than expected. By 2060, environmental damages in South and South Asia may lower GDP by more than five per cent compared to the central scenario.

China's growth is good for the world economy with significant terms of trade gains being experienced in its trading partners, reduction in poverty and increases in living standards. Chinese economic growth has been good for Chinese with massive reductions in poverty and rising living standards. Moreover, China is now a very large regional power and the preceding discussion has provided evidence that it is having a very large growth effect on its neighboring trade partners. If China continues its path of stable growth there is every reason to export continued and expanded benefits for its trade partners.

Rapid economic growth appears to have spread from China and others East/South Asia countries to Latin America and now Africa, and, while much of the old capitalist heard land is mired in economic stagnation and fiscal crisis, the "emerging economies" face an investment glut. Current trends in world economy and global politics provide evidence that the Global South has now arrived at "normal" capitalism at last, bringing with it new patterns of uneven development, inequality and injustice. Its newly confident elites, now fully engaged in global circuits of trade, investment and finance, and in global governance too, appear to have left behind their previous colonial role. It is clear that the Global South, or in elite-speak the "emerging economies", has suffered less and recovered more quickly that the advanced capitalist heartland. In addition, in 2011 it now seems that the patterns of political impact - not in the sense of immediate crisis measures but of long-term "tectonic" shifs - may be equally significant and unexpected. While political elites in the USA, European Union and Japan struggle to find pats of recovery that are acceptable to their confused and divided electorates, remarkable changes of various kinds are observable across Asia, Africa and Latin America.

\section{Conclusion}

Both structural and micro-political economy analyses of foreign trade policy have missed the impact of changing ideas about protectionism and relatively unchanging institutions designed to handle domestic producer complaints. The political consensus on the supply of trade policy and protectionism change over time In the economic depression tariffs revenues and protectionism play important roles in the politics of political parties. At the same time in the market economy even during the economic depression one can observe a little support for liberal foreign trade policy. In a global financial and economic crisis start to prevail also protectionist tendencies which accompanies economic recession. It is necessary to emphasize that in the foreign trade policy there are not pure liberalism and pure protectionism. In the high economic growth there are tendency to liberalism in the foreign trade policy and in the economic crisis there are tendency to protectionism. 
The foreign trade policy plays a key role in the maintenance of both economic and political liberalization. The prominence of rent seeking in a country can have far-reaching implication for its economic development. Especially in underdeveloped or transitional countries, rent seeking takes scarce resource out of productive areas in the economy, using them to promote and/or perpetuate further rents. However it should be stressed that free trade in itself is not responsible for economic growth, but more significant are the determining macroeconomic stability and investment increasing.

\section{References}

Alt, J. E., Frieden, J., Gilligan, M. J., Rodrik, D., \& Rogowski, R. (1996). The political economy of international trade: Enduring puzzles and an agenda for inquiry. Comparative Political Studies, 29, 689-717.

Anderson, K. (1995). Lobbying incentives and the pattern of protection in rich and poor countries. Economic Development and Cultural Change, 43, 401-423.

Banerji, A., \& Ghanem H. (1997). Does the type of political regime matter for trade and labor market policies? The World Bank Economic Review, 11(1), 171-194.

Coleman, W. D. (1998). From protected development to market liberalism: Paradigm change in agriculture. Journal of European Public Policy, 5, 632-651.

Frey, B. S. (1984). The public choice view of international political economy. International Organization ,38,199-223.

Grossman, G., \& Helpman, E. (1994). Protection for sale. American Economic Review, 84(4), 833-850.

Hadenius, A., \& Teorell, J. (2007). Pathways from authoritarianism. Journal of Democracy, 18(1),145-156.

Hankla, Ch. R. (2006). Party strength and international trade: A cross national analysis. Comparative Political Studies, 39(9), $1133-1156$

Hankla, Ch. R., \& Kuthy, D. (2013). Economic liberalism in illiberal regimes authoritarian variation and the political economy of trade. International Studies Quarterly, A Journal of the International Studies Association, 57(3), 492-504 .

Kleinberg, K. B., \& Fordham, B. O. (2013). The domestic politics of trade and conflict. International Studies Quarterly, A Journal of the International Studies Association, 57(3), 605-619.

Kleinberg, K. B., \& Fordham, B. O. (2010). Trade and foreign policy attitudes. Journal of Conflict Resolution, 54(5), 687-914.

Magee, S. P., Brock, W.A., \& Young, L. B. (1989). Hole tariffs and endogenous policy theory political economy in general equilibrium. Cambridge: Cambridge University Press.

Milner, H. V. (1995). Resisting the protectionism temptation: Industry and the making of trade policy in France and the United States during the 1970s. In J. A. Frieden \& D. A. Lake (Eds.), International political economy: Perspectives on global power and wealth (3rd ed.) (pp. 639-665). New York: St. Martin's Press.

Milner, H. V., \& Yoffie, D. B. (1989). Between free trade and protectionism: Strategic trade policy and a theory of corporate trade demands. International Organization, 43, 239-272.

Nau, H. R. (1989). Domestic trade politics and the Uruguay round: An overview. In H. R. Nau (Ed.), Domestic trade politics and the Uruguay round. New York: Columbia University Press.

Nelson, D. (1988). Endogenous tariff theory: A critical review. American Journal of Political Science, 32, $796-837$.

Nielson, D. L. (2003). Supplying trade reform: Political institutions and liberalization in middle-income presidential democracies. American Journal of Political Science, 47, 470-491.

Olson, M. (1985). Space, agriculture and organization. American Journal of Agricultural Economics, 67, 928-937.

Olson, M. (1986). The exploitation and subsidization of agriculture in developing and developed countries. In A. Maunder \& U. Renborg (Eds.), Agriculture in a turbulent world economy (pp. 49-59). Gower, U. K. Aldershot.

Pekkanen, S. M., Solis, M., \& Katada, S. N. (2007). Trading gains for control: International forums and Japanese economic diplomacy. International Studies Quarterly, 51, 945-970.

Pepinsky, T. B. (2008). Capital mobility and coalitional politics: Authoritarian regimes and adjustment in Southeast Asia. World Politics, 60, 438-474.

Radice, H. (2015). Global capitalism. Selected essays. Routledge, Tylor \& Francis Group, London and New York

Rodrik, D. (1995). Political economy of trade policy. In G. Grossman \& K. Rogoff (Eds.), Handbook of international economics (Vol. 3) (pp. 1457-1494). Amsterdam: Elsevier Science.

Rogowski, R. (1989). Commerce and coalitions. Princeton, NJ: Princeton University Press, . 
Rogowski, R. (1987a). Political cleavages and changing exposures to trade. American Political Science Review, 81, $1121-1137$. Rogowski, R. (1987b). Trade and the variety of democratic institutions. International Organization, 41, $203-222$.

Sheingate, A. D. (2001). The rise of agricultural welfare state: Institutions and interests group power in the United States, France, and Japan. Princeton, NJ: Princeton University Press.

Thies, C. G., \& Porche, S. (2007). Crawfish tails: A curious tale of foreign trade policy making. Foreign Policy Analysis, 3 , 171-187.

Wright, J. (2008a). Do authoritarian institutions constrain? How legislatures affect economic growth and investment, American. Journal of Political Science, 52(2), 322-343

Wright, J. (2008b). Insurance or investment? How authoritarian time horizons impact foreign aid effectiveness. Comparative Political Studies, 41(7), 971-1000. 